\title{
A Review on the Evolution of Europe's Methods to Exert Influence on The Palestinian-Israeli Peace Process
}

\author{
Mohamad Chaher Morra \\ Geneva School of Diplomacy and International Relations, Geneva, Switzerland \\ Nivin Ali Ali \\ American University of Science and Technology, Beirut, Lebanon
}

\begin{abstract}
This review will assist to understand the evolution of Europe's methods to exert influence on the Palestinian-Israeli peace process specifically from 1973 to 2015 . Moreover, it was also noted that this will be essential in recognizing the evolution of European foreign policies. This study assists to understand the evolution of approaches agreed by the Europe since 1973 until present or 2015. This study focuses on the various approaches of actors from the civil society, private sector involved in the conflict between the Palestine and Israel. Moreover, this study will assist in understanding the evolution of Europe's methods and policies in the peace process between Israel and Palestine. Subsequently, this study focuses on the significance of non-state actors in the peace process between Palestine and Israel. This study clearly highlights the various strategies adopted by the Europe foreign policies in the conflict between Palestine and Israel. This study also highlights to what extent European foreign policy has assisted in the peace process between Israel and Palestine. This study would be useful to understand the effectiveness of European foreign policies in the peace process.
\end{abstract}

Keywords: Palestinian-Israeli Peace, Europe’s Method, Peace Process, foreign policy, diplomacy

\section{Introduction}

According to Chopra and Hohe (2004) and Chopra et al. (2004), the first official influence of European Commision (EC) was held in the Israeli-Palestinian conflict during the late 1970's Yom Kippur War and resulted in a global oil crisis. After one month, EC issued a declaration by understanding the Palestinians' legitimate rights, thus calling for withdrawal of Israeli from all territories used during Israeli-Arab war in 1967 (Chopra \& Hohe, 2004; Hollis, 2010). Further the EC had began "Euro-Arab Dialogue" to reinforce better understanding with the Arab nation. Such actions had made a historic change in the attitudes of Europe people towards Israel, where committed support had reduced in the year 1973 (Chopra et al., 2004). Hollis (2010) and Krotz (2009) pointed out that European Union is a significant factor in the conflict between Israeli and Palestine for economic, political and historical reasons. Further Hollis (2010) had pointed out that EU is Israel's biggest foreign aid provider and largest trading partner to the Palestinians.

According to Dannreuther (2002) and Hollis (2010), During the 70s and 80s, the approach of Europe to

Mohamad Chaher Morra, Ph.D. candidate, Department of International Relations, Geneva School of Diplomacy and International Relations.

Nivin Ali Ali, Bachelor of Science, Department of Business and Economics, American University of Science and Technology. 
handle the conflict between the Israel and Palestine was on the basis of elaborating the declaratory policy. This is mainly due to some main reasons. Krotz (2009) and Dannreuther (2002) stated that first and foremost EC did not include a coherent foreign policy instrument that is capable of including both the general aspects of European cooperation and intergovernmental cooperation. European Political Cooperation (EPC) was relied on agreement degree between the member states that had the freedom or right to take any decision (Chopra \& Hohe, 2004; Dannreuther, 2002). Second one is that member states mostly do not share the same perspective on how to address the flight or conflict. Such difference on appreciation involved a lack of political will (Chopra et al, 2004; Hollis, 2010).

Stephens (2004) and Steinberg (2004) stated that there is critique in the role of European Union in the relations of Israel and Palestine, while the Authority of Palestinian welcome direct intervention of EU as balancing what they view as bias between the Palestine and Israel (Steinberg, 2004; Aoun, 2003). Stetter (2003) mentioned that Israel had built an ambivalent relationship with the European Union. Policy of EU does not vary from the policy of USA based on the demand for a two Palestine and Israel solution, a full freeze on activity for settlement, unilateral construction cessation of isolation fence, cessation of violence and the requirement for internal democratic and economic reforms in the Palestine (Newman \& Yacobi, 2004; Chopra \& Hohi, 2004). USA and EU are equal partners in the quartet which developed the plan for road map for peace and that was originally presented to leaderships of both Palestine and Israel (Dosenrode-Lynge \& Stubkjaer, 2002). European Union has argued its preference for expanding viable, democratic, sovereign and peaceful state of Palestine, based on 1967 borders if needed with small adjustments agreed by the parties (Hollins, 2010; Dosenrode-Lynge \& Stubkjaer, 2002).

\section{Problem Identified}

Undoubtedly, the conflict between the Palestine and Israel, instability source occupies a high ranking position in the European officials' agenda. Morally and historically responsible for the entrance of Israeli state and question Palestinian's, Europe could never allow in order to stay in the affairs of Middle East margins (Asseburg, 2003; Aoun, 2003). Conversely, geographical proximity favors and imposes, the development of commercial, economic, religious, political and social ties between the two Mediterranean Sea shores (Aoun, 2003; Newman \& Yacobi, 2004). The institutional diplomatic system evolution of Europe affects from primordial flaw, unchangeable and constant critique of all researchers concentrating on the integration process of Europe such as lack of coherent and external action (Asseburg, 2003; Chopra et al, 2004), primarily because of absence of foreign policy approach pooling the intergovernmental and common elements of Europe's external activity (Del Sarto \& Schumacher, 2005; Newman \& Yacobi, 2004). Therefore, this study in detail investigates about the evolution of Europe's methods to exert influence on the Palestinian-Israeli Peace process: 1973-2014.

\section{Theoretical Framework}

There are many studies and researchers that focused on the conflict existing between Palestians and Israeli. Many authors focused on the planning considerations for international involvement in the conflict that exist between Palestinian and Israeli. Their study focused on the international involvement that is Europe and United States involvement in the conflict between the two states (Chopra et al., 2004). Dannreuther (2002) conducted a 
research to understand the relationship between the Europe and Middle East. It focused on the Europe and Middle East towards a substantive role in the process of peace.

Del Sarto and Schumacher (2005) discussed about EMP to ENP and focused on stake with the European neighbored towards the Southern side of the Mediterranean Sea. There are also studies that focused on the European Union and the Arab-Iraeli Peace process (Constanza, 2007). Dosenrode-Lynge and Stubkjaer (2002) focused on the European Union and the Middle East. This study focused on the various evolutions of policies of the European Union adopted in the conflict between the Middle East. Authors also concentrated on the European Union and the transformation of border conflicts and also this study concentrated on the theorizing the effect of integration and association (Diez, Stetter, \& Albert, 2003).

Newman and Yacobi (2004) conducted a research to concentrate on the role of European Union in the Israel and Palestine conflict. Hollis (2010) concentrated on basic stakes and strategy of the EU and the member states and also European involvement in the conflict between Israel and Arab. Shlaim (2005) examined the Europe role and the bias between the Palestinian and Israel. There are also studies that focused on the European Union involvement in the conflict existing between Israel and Palestinian. This study also focused on the active paradigm of foreign policy related to Europe (Gianniou, 2006).

However, there has been no specific study that focused on the evolution of Europe's methods to exert influence on the Palestinian-Israeli Peace process with specific analysis since 1973 until 2015. Therefore this study tries to bridge that gap by analyzing in detail about the evolution of Europe's methods to exert influence on the Palestinian-Israeli Peace process with specific reference from 1973 to 2015. Moreover, this research focuses on the significance or growth of non-state actors in the Palestinian-Israeli peace process.

\section{Preliminary Literature Review}

Firstly, this section focuses on the various challenges faced by the Europe in solving the conflict between Palestine and Israel. Next to that, it critically reviews the role of Europe in the conflict between Palestine and Israel. According to European Union (2008), European Union has at its disposal certain unique diplomatic instruments which could search for crisis management and multilateral solutions most notably: European Union (EU) special Envoy (EUSR), Euro-Mediterranean Partnership (EMP) and the European Union's participation in the Quartet. Apart from these another notable solution is European Neighborhood Policy (ENP). These tools effectiveness could be reasonably questioned (Dosenrode-Lynge \& Stubkjaer, 2002; European Union, 2008).

Del Sarto and Schumacher (2005) pointed out that EMP has given a forum for multilateral diplomatic that integrate Israel and number of Arab nations in a trail to promote dialogue as well as understanding. EMP was developed to complement the process of peace. It was assumed to support development in economy and expand the foundation for civil society cooperation and regional integration. At the same time, as long as the process of peace remains floundering and fragile the EMP itself and then EMP would not able to have its anticipated impact. Rather agreed that EMP had failed to achieve its objectives and thus new strategies are required. Such realization has lead Europe to concentrate on ENP. Unlike EMP, ENP searches to deeply focus on the bilateral relations between European Union and the nations of Middle East (European Union, 2008; Raffaella et al., 2005).

Tocci (2005) mentioned that by performing this, it would provide rewards and incentives to the countries 
of Middle East that would like to participate in thorough domestic reforms. This could be done with the "joint action plans" adoption that gives a schedule for domestic reforms and focuses on the EU rewards. Del Sarto and Schumacher (2005) pointed out that both Palestine and Israel adopted "joint action plans in the year 2005 with the EU, even though little progress has developed on EU-PA action plan, because of EU's relations suspension with it (Tocci, 2005). At the same time, neither of such plans made clear conditions in terms of final talks about the settlement. Carrots given by the ENP particularly in case of Israel are not that much significant to serve as incentive for urging the Palestine and Israel towards negotiations. Thus, ENP failed to give the EU with a main role in negotiations of peace (Del Sarto \& Schumacher, 2005; Tocci, 2005).

Furthermore, Constanza (2007) and Tocci (2005) stated that next to that EUSR played a prominent role in de-escalating the tensions and crisis management. There are numerous barriers to EU in receiving a powerful role in the process of peace. Israel has identified sympathetic support for foreign policies in US which could influence an efficient and large pro-Israeli lobby. Conversely, EU's approach based on the balance of pro-Palestinian and pro-Israeli lobbying forces inside Europe, functioned by the historical contingency. This indicates that in the past history Israel had granted US the preferred mediator status, whereas adopting only more restricted EU involvement. In some cases, Israel has sought to ruin the pro-active role of Europe in the process of peace (Del Sarto \& Schumacher, 2005).

Newman and Yacobi (2004) discussed about the role of European Union in the conflict between Israel and Palestine. The aim and objective of this research is to examine whether and under what conditions, the involvement of European Union in the arena of Palestine and Israel has had any direct effect on the conflict resolution process. It also examines the various pathways specifically enabling effect, compulsory effect, constructive effect and connective effect that the EU have applied in the conflict between Palestine and Israel (Diez, Stetter, \& Albert, 2003).

It was indicated that there have been endeavor at changing the conflict through agents of civil society in Palestine and Israel. This research was carried out among Palestinian and Israeli. From the findings of research, Israel and Palestine relations could be best explained as that constitutes an escalating conflict in the power; it is on the basis of violence as the major communication form; physical force was dealing among IP relations. The ability to transform the conflict between Israel and Palestine through the compulsory path is restricted. From the Israeli perspective, there is a clear manipulation and denial of the EU carrot and stick approach; relations in the economy are understood as too significant to the Europeans for withdrawal to be deployed, whereas such act would be self-defeating which would in turn Israel to be against Europe and further into American ally arms. On the other hand, connective path seems to be a major EU intervention form in Palestine and Israel. From the Palestinian perspective, it is mostly seen positively and to some what it leads to independence for example the expansion of civil society and so on; on the Israeli point of view, it was understood by more critics as an alternative way of supporting the agendas of post Zionist (Newman \& Yacobi, 2004).

Likewise Shlaim (2005) pointed out the role of EU in promoting a genuine solution to the conflict between Palestine and Israel. Europe would provide long term benefits for Israel by finishing its occupation by another person as well as by permitting it for channelizing its energies towards constructive ends. Europe would help the Palestinians in understanding their long-denied desires to statehood and independence. It would assist the moderate states of Arab nations; all people would be destabilized by the second intifada violence. In all these unique ways, Europe had contribution for the resolution for the IA relations for regional stability. Further, 
Gianniou (2006) conducted a study to focus on the involvement of EU in the conflict between Palestinian-Israeli and also focuses on an active paradigm of foreign policy in the Europe. The study of European action towards the conflict between Israeli and Palestinian highlights the two notifications. Europe acts an international actor in the affirmation and its dedication to the conflict seen as a political actor. Europe has managed through a European foreign policy for the conflict between IA relations and through progressive focus on the set of fundamental principles, inferred inside the framework of EPC and further adopted on the ground through tangible and concrete actions.

In addition to that, Persson (2009) focused on the transformation of just peace with specific analysis of EU and the Middle East process of peace. This study concentrates on how the EU has conceptualized peace in the conflict between Israeli and Palestine over the past 40 years and recognizes five phases of various conceptualizations' of peace in narrating European Union. First three phases occurred in 1970s at the time of EC (European commission) approving Security Council resolution and understood the Palestinians as a fight with legitimate rights encompassing a homeland. It was noted that last two phases occurred in 1980s and 1990swhen the European commission or European Union initiated the rights of Palestine to "exercise fully its right to self-determination" and state for Palestine (Persson, 2009).

\section{Conclusion}

This review will be further elaborated with a more detailed research that will involve research methodology using instruments like survey and interviews. This review is kick start for a long and awesome $\mathrm{PhD}$ journey and research by the author. It is hope the review and ideas shared can add some lights to the knowledge on the evolution of Europe's methods to exert influence on the Palestinian-Israeli peace process.

\section{References}

Assenburg, M. (2003). EU and Middle East conflict: Tackling the main obstacle to Euro-Mediterranean partnership. Mediterranean Politics, 8(2), 174-193.

Aoun, E. (2003). European foreign policy and the Arab Israeli dispute: Much ado about nothing. European Foreign Affairs Review, 8(3), 289-312.

Chopra. J. et al (2004). Planning considerations for international involvement in the Israeli-Palestinian conflict. Working Report of Track Negotiations.

Chopra, J., \& Hohe. T. (2004). Participatory interfention. Global Governance, 10, 289-305.

Constanza, M. (2007). The EU and the Arab-Israeli peace process. In N. Casarini and C. Musu (Eds.), European foreign policy in an evolving international system, the roads towards convergence (pp. 112-127). Palgrace macmillan.

Dannreuther, R. (2002). Europe and the Middle East: Towards a substantive role in the peace process? Geneva Center for Security Policy, Occasional Paper Series No. 39.

Del Sarto, R. A., \& Schumacher, T. (2005). From EMP to ENP: What's at Stake with the European Neighbored towards the Southern Mediterranean. European Affairs Review, 10(1), 17-38.

Diez, T., Stetter, S., \& Albert, M. (2003). The European Union and the transformation of border conflicts: Theorizing the impact of integration and association. Paper for presentation at the BISA Annual Conference (pp. 15-17), University of Birmingham.

Dosenrode-Lynge, S. Z., \& Stubkjaer, A. (2002). The European Union and the Middle East. London, Sheffield Academic.

European Union. (2008). Europe's role in the Palestinian-Israeli Conflict. European Union Center of North Carolina EU Briefings.

Gianniou, M. (2006). The EU's involvement in the Israeli-Palestinian conflict: An active paradigm of European foreign policy. 3rd Pan-European Conference on EU Policies.

Hollis, R. (2010). The basic stakes and strategy of the EU and Member States. European involvement in the Arab-Israeli conflict Chaillot Paper 124.16 
Krotz, U. (2009). Momentum and impediments: Why Europe won't emerge as a full political actor on the world stage soon. Journal of Common Market Studies, 47(3), 557-57

Newman, D., \& Yacobi, H. (2004). The role of the EU in the Israel and Palestine conflict.. EU Border Conflicts Studies.

Persson, A. (2009). The transformation of just peace: EU and the Middle East peace process. Retrieved from November 18, 2014, from http://www4.lu.se/upload/LUPDF/Samhallsvetenskap/Just_and_Durable_Peace/AndersPersson.pdf

Stephens, B. (2004). Europe and Israel: What went wrong? January 2nd, 2004.

Steinberg, G. M. (2004). Learning the lessons of the European Union's failed Middle East Policies, Jerusalem Viewpoints. Paper Presented at The Conference on Troubled Waters: Europe and its relations with the US and Israel.

Stetter, E. S. (2003). Cross pillar politics of the European Union-EU actors and the centralization of foreign and interior policies. London School of Economics and Political Science.

Shlaim, A. (2005). Europe and the Israeli-Palestinian Conflict. Oxford Research Group.

Tocci, N. (2005). Does the European Union promote democracy in Palestine? In M. Emerson (Ed.), Democratization in the European neighborhood (pp. 131-168). Brussles: Center for European Policy Studies. 